\title{
PENENTUAN TARIF JASA LUKIS DENGAN MENERAPKAN METODE ANAL YTICAL HIEARARCHY PROCESS
}

\author{
Rian Wahyu Noviantoro ${ }^{1}$, Sri Lestanti ${ }^{2}$ \\ 1,2 Teknik Informatika S1 Universitas Islam Balitar \\ mongoding.dev@gmail.com
}

\begin{abstract}
ABSTRAK
Pelukis foto merupakan pelaku usaha yang bergerak dibidang jasa lukis dengan foto sebagai objeknya, tarif yang ditawarkanpun beragam sesuai dengan jenis lukisan yang dipesan, perbedaan jenis ini menjadikan pelukis/seniman harus lebih teliti terhadap tarif yang ditawarkan. Namun didalam sebuah komunitas kerap kali terdapat persaingan harga yang terlalu mencolok diantara anggotanya. Oleh karena itu, diperlukan sebuah sistem pendukung keputusan untuk membantu para pelukis yang tergabung dalam komunitas lukis BlitArt memutuskan tarif terendah dengan kriteria yang ada, sesuai dengan kesepakatan yang telah disetujui oleh masing - masing anggota komunitas yaitu ukuran kertas, jumlah objek (kepala), tingkat kerumitan dan jenis lukisan. Metode yang akan digunakan pada penelitian ini adalah Research and development sebagai metode pengembangan sistem dan metode Analitycal Hieararchy Process (AHP). Data alternatif yang digunakan pada penilitian ini adalah 15 lukisan yang sering dipesan oleh pelanggan dengan persentase kesalahan sebesar 25\% dimana tarif tersebut memiliki selisih harga lebih rendah $\mathrm{Rp} 25.000$ dari tarif yang dietetapkan saat ini. Sistem yang telah selesai dibuat kemudian diuji dengan metode blackbox testing untuk menguji fungsionalitas tombol dan fitur pada aplikasi dengan perolehan nilai sebesar $100 \%$, dilanjut dengan pengujian logika sistem menggunakan meode whitebox testing dan mendapatkan nilai yang sama dari tiga tahapan penggujian yaitu 7 dimana nilai 7 ini menunjukan bahwa aplikasi memiliki algoritma yang terstruktur, kode ditulis dengan baik, memiliki kemampuan pengetesan tinggi, kemudian rancangan sistem membutuhkan biaya dan usaha yang rendah.
\end{abstract}

Keyword : Jasa Lukis, Sistem Pendukung Keputusan, Analitycal Hierarchy Process (AHP)

\section{PENDAHULUAN}

\subsection{Latar Belakang}

Pelukis foto merupakan usaha yang bergerak dibidang jasa lukis dengan foto sebagai objeknya. Apriya yang merupakan salah satu anggota dari komunitas lukis BlitArt mengatakan "tarif yang diberikan bermacam - macam sesuai dengan jenis lukisan yang diinginkan pelanggan, perbedaan jenis lukisan menjadikan pelukis/seniman harus lebih teliti terhadap tarif yang ditawarkan, misalnya dari segi ukuran lukisan dan jumlah objek yang berbeda maka membuat tarif yang berbeda juga."

Sistem penentuan tarif jasa lukis diharapkan mampu membantu para pelukis khusunya yang targabung pada komunistas Blitart untuk menciptakan standar harga terendah agar tidak terjadinya persaingan harga yang mencolok antar anggota dengan kriteria-kriteria yang sudah disepakati yaitu ukuran kertas, jumlah objek (kepala), tingkat kerumitan dan jenis

Di era digital ini semua usaha sudah mulai memanfaatkan teknologi jaringan internet, diantaranya adalah penggunaan website untuk memudahkan pekerjaan sehari - hari. Website merupakan kumpulan halaman-halaman yang digunakan untuk menampilkan informasi teks, gambar diam atau bergerak, animasi, suara, dan atau gabungan dari semuanya, baik yang bersifat statis maupun dinamis yang membentuk satu rangkaian bangunan yang saling terkait, yang masing-masing dihubungkan dengan jaringan-jaringan halaman [1].

Pada tahun 2020 disebutkan bahwa ada 175,4 juta pengguna internet di Indonesia. Dibandingkan tahun sebelumnya, ada kenaikan $17 \%$ atau 25 juta pengguna internet di negeri ini. Berdasarkan total populasi Indonesia yang berjumlah 272,1 juta jiwa, artinya 64\% setengah penduduk RI telah merasakan akses ke dunia maya [2]. Dari data tersebut penulis membuat suatu aplikasi sistem pendukung keputusan dan ditambah metode Analitycal Hieararchy Process (AHP) untuk perangkainya, AHP diharapkan dapat menghasilkan nilai yang sesuai dengan menggunakan banyak kriteria. Setiap kriteria memiliki bobot yang berbeda - beda pada setiap alternatif, penentuan bobot dadpat dilakukan dengan mengunakan AHP karena dapat dihitung secara kualitatif [3].

Oleh karena itu dengan memanfaatkan teknologi yang sudah ada, peneliti mencoba dengan menerapkan judul "penentuan tarif jasa lukis foto menerapkan metode AHP”.

\subsection{Pembatasan Masalah}

Agar proses penelitian dan pembahasan tidak terlalu luas, maka masalah yang ada harus dibatasi. Adapun batasan masalah dalam penelitian ini sebagai berikut:

1. Pada aplikasi ini ditujukan untuk komunitas lukis BlitArt yang anggotanya terdiri dari beberapa pelaku usaha jasa lukis foto di Blitar.

2. Pada aplikasi ini berisi informasi tentang tarif jasa lukis foto dengan menerapkan metode AHP.

3. Pembuatan aplikasi menggunakan Codeigntier 3 dan MySQL. 
4. Metode pengujian yang digunakan adalah penguujian Black box dan White box.

\section{LANDASAN TEORI}

\subsection{Tinjauan Pustaka}

Penelitian ini berdasarkan penelitian sebelumnya yang dilakukan oleh Mahyadi Prabowo (2019) dengan judul "Sistem Informasi Pedoman Seni Lukis (Realisme) Berbasis Android". Permasalahan yang muncul dalam penelitian ini adalah semakin banyaknya generasi muda dan orang tua yang menyukai seni lukis wajah, namun ruang merupakan media pembelajaran bagi mereka yang masih pemula untuk mengetahui cara membuat atau melukis wajah, khususnya cara membuat arsiran dan garis. Sistem informasi ini dibuat dengan menggunakan metode simulasi untuk menyajikan cara melukis wajah dengan benar dan berbasis android.

Penelitian selanjutnya dilakukan oleh Anisya (2017) yang berjudul "Sistem Pendukung Keputusan Analytical Hierarchy Process (AHP) Distribusi Beras Keluarga Miskin". Dalam penelitian ini peneliti menyimpulkan bahwa Metode Analytic Hierarchy Process (AHP) dapat diimplementasikan untuk menyelesaikan permasalahan pembagian beras untuk keluarga miskin dengan menggunakan 12 kriteria yang terdiri konsdisi atap, lantai, dinding, ukuran rumah, kepemilikan rumah, penghasilan, pekerjaan, jumlah tanggungan, kebun, ternak, elektronik, dan kendaraan

\subsection{Sistem Pendukung Keputusan}

Konsep Sistem Pendukung Keputusan (SPK) atau Decision Support Systems (DSS) merupakan suatu penerapan sistem informasi yang ditunjukan untuk membantu pimpinan atau individu dalam proses pengambilan keputusan. Sistem Pendukung Keputusan menggabungkan kemampuan komputer dalam pelayanan interaktif dengan pengolahan data yang memanfaatkan model atau aturan penyelesaian yang tidak terstruktur. Sistem Pendukung Keputusan didefinisikan sebagai sebuah sistem yang dimaksudkan untuk mendukung para pengambil keputusan dalam situasi tertentu untuk memperluas kapabilitas pengambilan keputusan mereka, namun tidak menggantikan penilaian mereka [4].

Proses pengambilan keputusan, pengolahan data dan informasi yang dilakukan bertujuan untuk menghasilkan berbagai alternatif keputusan yang dapat diambil. SPK yang merupakan penerapan dari sistem informasi ditujukan hanya sebagai alat bantu manajemen dalam pengambilan keputusan. SPK tidak dimaksudkan untuk menggantikan fungsi pengambil keputusan dalam membuat keputusan, melainkan hanyalah sebagai alat bantu pengambil keputusan dalam melaksanakan tugasnya. SPK dirancang untuk menghasilkan berbagai alternatif yang ditawarkan kepada para pengambil keputusan dalam melaksanakan tugasnya. Sehingga dapat dikatakan bahwa SPK memberikan manfaat bagi manajemen dalam hal meningkatkan efektivitas dan efisiensi kerjanya terutama dalam proses pengambilan keputusan. Di samping itu, SPK menyatukan kemampuan komputer dalam pelayanan interaktif terhadap penggunanya dengan adanya proses pengolahan atau pemanipulasian data yang memanfaatkan model atau aturan yang tidak terstruktur sehingga menghasilkan alternatif keputusan yang situasional [5]

\subsection{Analitycal Hieararchy Process (AHP)}

Analitycal Hieararchy Process (AHP) merupakan suatu model pendukung keputusan yang dikembangkan oleh Thomas L. Saaty. Model pendukung keputusan ini akan menguraikan masalah multi factor atau multi kriteria yang kompleks menjadi suatu hirarki. Masalah yang kompleks dapat di artikan bahwa kriteria dari suatu masalah yang begitu banyak (multikriteria),struktur masalah yang belum jelas, ketidakpastian pendapat dari pengambil keputusan, pengambil keputusan lebih dari satu orang, serta ketidakakuratan data yang tersedia. Hirarki didefinisikan sebagai suatu representasi dari sebuah permasalahan yang kompleks dalam suatu struktur multilevel dimana level pertama adalah tujuan, yang diikuti level faktor, kriteria, sub kriteria, dan seterusnya kebawah hingga level terakhir yaitu alternatif [6]. Dengan hirarki, suatu masalah yang kompleks dapat diuraikan kedalam kelompok-kelompoknya yang kemudian diatur menjadi suatu bentuk hirarki sehingga permasalahan akan tampak lebih terstruktur dan sistematis. AHP sering digunakan sebagai metode pemecahan masalah dibanding dengan metode yang lain karena alasan-alasan sebagai berikut :

1. Struktur yang berhirarki, sebagai konsekuesi dari kriteria yang dipilih, sampai pada subkriteria yang paling dalam.

2. Memperhitungkan validitas sampai dengan batas toleransi inkonsistensi berbagai kriteria dan alternatif yang dipilih oleh pengambil keputusan.

3. Memperhitungkan daya tahan output analisis sensitivitas pengambilan keputusan.

\section{METODE PENELITIAN}

Metode pengumpulan data yang dianggap sesuai dengan permasalahan yang ada dalam penelitian ini adalah metode kualitatif dimana dalam pelaksanaanya dilakukan wawancara bertempat di area Perpustakaan Bung Karno Jl. Kalasan No.1, Kelurahan Bendogerit, Kecamatan Sananwetan, Kota Blitar, bersama dengan anggota komunitas lukis BlitArt. 


\subsection{Flowchart Sistem}

Berdasarkan hasil analisa, maka perlunya pembuatan aplikasi penentuan tarif jasa lukis foto sehingga dapat membantu komunitas BlitArt dalam memberikan tarif jasa lukis foto dengan melihat bobot total setiap alternatif berdasarkan hasil perhitungan dengan menggunakan beberapa kriteria yang telah ditetapakan sebelumnya. Berikut flowchart sistem yang digunakan dalam aplikasi ditampilkan pada gambar 1 :

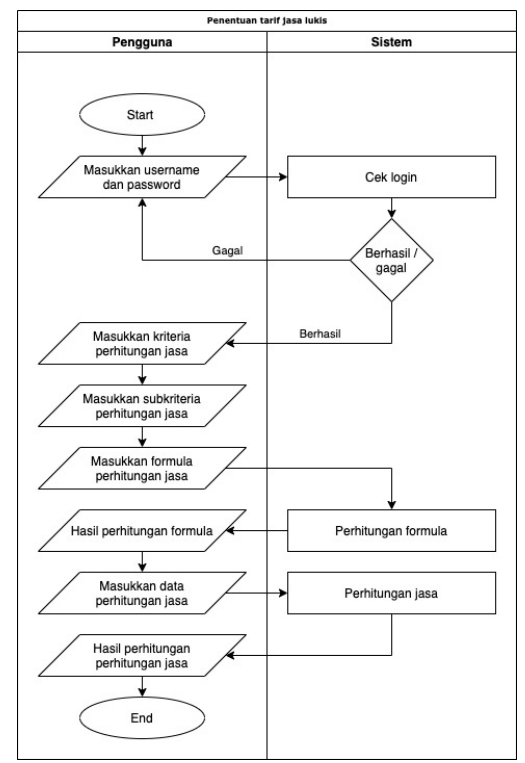

Gambar 1. Flowchart Sistem

\subsection{Data Flow Diagram (DFD)}

Untuk menggambarkan perancangan proses, pengguna dapat melakukan login dalam sistem ini mempunyai kewenangan untuk mengatur dan mengelolah data-data serta proses yang ada di dalam sistem, yaitu melakukan proses manipulasi seluruh data yang tersedia, seperti mengedit dan menghapus data. Adapun diagram konteks dari sistem pendukung keputusan yang akan dibangun dapat dilihat pada gambar 2.

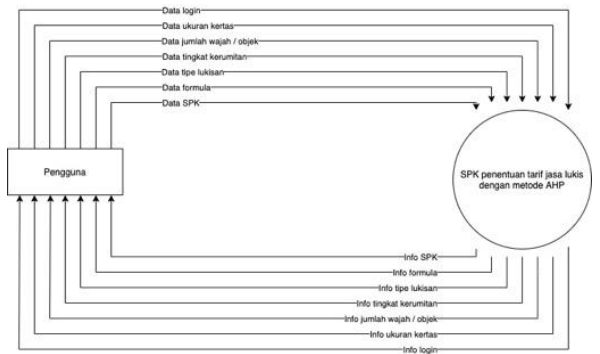

Gambar 2. Diagram Konteks

\subsection{Pemodelan Data}

ERD (Entity Relationship Diagram) merupakan suatu bentuk yang didasarkan pada dunia nyata yang tersusun atas objek-objek dasar yang disebut entitas yang saling berhubungan antara entitas yang satu dengan yang lain pada sebuah database, seperti gambar 3.

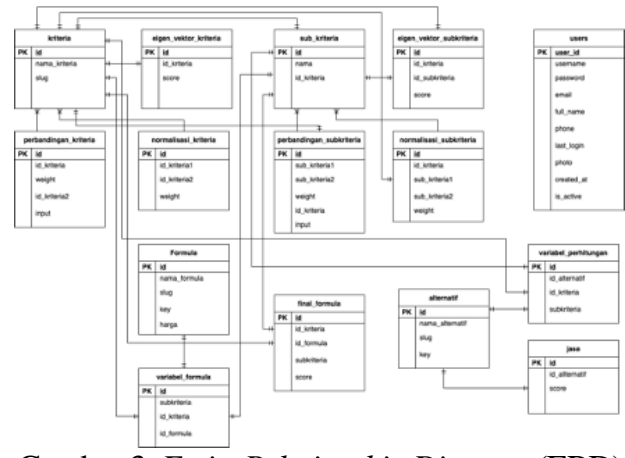

Gambar 3. Entity Relationship Diagram (ERD)

\subsection{Penerapan Kriteria dan Contoh}

Perhitungan Menggunakan Metode AHP

Terdapat empat kriteria yang telah disepakati oleh anggota komunitas BlitArt yang nantinya digunakan pada penelitian ini yaitu ukuran kertas, jumlah objek, kerumitan dan jenis lukisan.

1. Kriteria Ukuran Kertas (UK)

Tabel 1. Kriteria Ukuran Kertas

\begin{tabular}{|c|c|c|}
\hline No & Inisialisasi & Subkriteria \\
\hline 1 & A1 & Kertas A1 \\
\hline 2 & A 2 & Kertas A2 \\
\hline 3 & A3 & Kertas A3 \\
\hline 4 & A4 & Kertas A4 \\
\hline
\end{tabular}

2. Kriteria Jumlah Objek (JO)

Tabel 2. Kriteria Jumlah Objek

\begin{tabular}{|c|c|c|}
\hline No & Inisialisasi & Subkriteria \\
\hline 1 & 1 & 1 objek \\
\hline 2 & 2 & 2 objek \\
\hline 3 & 3 & 3 objek \\
\hline 4 & 4 & 4 objek \\
\hline 5 & 5 & 5 objek \\
\hline 6 & 6 & 6 objek \\
\hline
\end{tabular}

3. Kriteria Kerumitan (KR)

Tabel 3. Kriteria Kerumitan

\begin{tabular}{|c|c|c|}
\hline No & Inisialisasi & Subkriteria \\
\hline 1 & SR & Sangat rumit \\
\hline 2 & R & Rumit \\
\hline 3 & S & Sedang \\
\hline 4 & M & Mudah \\
\hline
\end{tabular}

4. Kriteria Jenis Lukisan (JL)

Tabel 4. Kriteria Jenis Lukisan

\begin{tabular}{|c|c|c|}
\hline No & Inisialisasi & Subkriteria \\
\hline 1 & KW & Karikatur warna \\
\hline 2 & KH & Karikatur hitam putih \\
\hline 3 & RW & Realis warna \\
\hline 4 & RH & Realis hitam putih \\
\hline 5 & SB & Sketsa biasa \\
\hline
\end{tabular}


5. Eigen Vector Kriteria

Tabel 5. Eigen Vector Kriteria

\begin{tabular}{|c|c|c|c|c|c|c|}
\hline & UK & JO & KR & JL & Jumlah & $\begin{array}{l}\text { Eigen } \\
\text { Vector }\end{array}$ \\
\hline UK & 0.5357 & 0.5581 & 0.5263 & 0.4615 & 2.0817 & 0.5204 \\
\hline JO & 0.2679 & 0.2791 & 0.3158 & 0.3077 & 1.1704 & 0.2926 \\
\hline KR & 0.1071 & 0.093 & 0.1053 & 0.1538 & 0.4593 & 0.1148 \\
\hline JL & 0.0893 & 0.0698 & 0.0526 & 0.0769 & 0.2886 & 0.0722 \\
\hline
\end{tabular}

6. Eigen Vector Subkriteria Ukuran Kertas

Tabel 6. Eigen Vector Subkriteria Ukuran Kertas

\begin{tabular}{|c|c|c|c|c|c|c|}
\hline & A1 & A2 & $\mathbf{A 3}$ & $\mathbf{A 4}$ & Jumlah & $\begin{array}{c}\text { Eigen } \\
\text { Vector }\end{array}$ \\
\hline A1 & 0.48 & 0.5217 & 0.4615 & 0.4 & 1.8633 & 0.4658 \\
\hline A2 & 0.24 & 0.2609 & 0.3077 & 0.3 & 1.1086 & 0.2771 \\
\hline A3 & 0.16 & 0.1304 & 0.1538 & 0.2 & 0.6443 & 0.1611 \\
\hline A4 & 0.12 & 0.087 & 0.0769 & 0.1 & 0.3839 & 0.096 \\
\hline
\end{tabular}

7. Eigen Vector Subkriteria Jumlah Objek

Tabel 7. Eigen Vector Subkriteria Jumlah Objek

\begin{tabular}{|c|c|c|c|c|c|c|c|c|}
\hline & $\mathbf{6}$ & $\mathbf{5}$ & $\mathbf{4}$ & $\mathbf{3}$ & $\mathbf{2}$ & $\mathbf{1}$ & Jumlah & $\begin{array}{c}\text { Eigen } \\
\text { Vector }\end{array}$ \\
\hline $\mathbf{6}$ & 0.4082 & 0.4669 & 0.4235 & 0.3692 & 0.3226 & 0.2857 & 2.2761 & 0.3794 \\
\hline $\mathbf{5}$ & 0.2041 & 0.2335 & 0.2824 & 0.2769 & 0.2581 & 0.2381 & 1.493 & 0.2488 \\
\hline $\mathbf{4}$ & 0.1361 & 0.1167 & 0.1412 & 0.1846 & 0.1935 & 0.1905 & 0.9626 & 0.1604 \\
\hline $\mathbf{3}$ & 0.102 & 0.0778 & 0.0706 & 0.0923 & 0.129 & 0.1429 & 0.6146 & 0.1024 \\
\hline $\mathbf{2}$ & 0.0816 & 0.0584 & 0.0471 & 0.0462 & 0.0645 & 0.0952 & 0.393 & 0.0655 \\
\hline $\mathbf{1}$ & 0.068 & 0.0467 & 0.0353 & 0.0308 & 0.0323 & 0.0476 & 0.2607 & 0.0434 \\
\hline
\end{tabular}

8. Eigen Vector Subkriteria Kerumitan

Tabel 7. Eigen Vector Kerumitan

\begin{tabular}{|c|c|c|c|c|c|c|}
\hline & SR & $\mathbf{R}$ & $\mathbf{S}$ & $\mathbf{M}$ & Jumlah & $\begin{array}{l}\text { Eigen } \\
\text { Vector }\end{array}$ \\
\hline SR & 0.603 & 0.6545 & 0.5357 & 0.5 & 2.2933 & 0.5733 \\
\hline $\mathbf{R}$ & 0.201 & 0.2182 & 0.3214 & 0.25 & 0.9906 & 0.2477 \\
\hline $\mathbf{S}$ & 0.1206 & 0.0727 & 0.1071 & 0.1875 & 0.488 & 0.122 \\
\hline $\mathbf{M}$ & 0.0754 & 0.0545 & 0.0357 & 0.0625 & 0.2281 & 0.057 \\
\hline
\end{tabular}

9. Eigen Vector Subkriteria Jenis Lukisan

Tabel 8. Eigen Vector Jenis Lukisan

\begin{tabular}{|c|c|c|c|c|c|c|c|}
\hline & KW & KH & RW & RH & SB & Jumlah & $\begin{array}{l}\text { Eigen } \\
\text { Vector }\end{array}$ \\
\hline KW & 0.438 & 0.4898 & 0.4557 & 0.3478 & 0.3125 & 2.0438 & 0.4088 \\
\hline KH & 0.219 & 0.2449 & 0.3038 & 0.2609 & 0.25 & 1.2785 & 0.2557 \\
\hline RW & 0.146 & 0.1224 & 0.1519 & 0.2609 & 0.25 & 0.9312 & 0.1862 \\
\hline RH & 0.1095 & 0.0816 & 0.0506 & 0.087 & 0.125 & 0.4537 & 0.0907 \\
\hline SB & 0.0876 & 0.0612 & 0.038 & 0.0435 & 0.0625 & 0.2928 & 0.0586 \\
\hline
\end{tabular}

10. Rata-rata harga terendah yang telah disepakati antar anggota dengan kriteria ukuran kertas sebagai parameter kunci yang akan digunakan sebagai formula. 
Tabel 9. Variabel Formula

\begin{tabular}{|l|l|l|l|l|c|}
\hline Formula & UK & JO & KR & JL & $\begin{array}{l}\text { Harga } \\
\text { Terendah }\end{array}$ \\
\hline Formula A1 & A1 & 1 & M & RH & 745000 \\
\hline Formula A2 & A2 & 1 & M & RH & 450000 \\
\hline Formula A3 & A3 & 1 & M & RH & 255000 \\
\hline Formula A1 & 1 & 1 & M & RH & 153000 \\
\hline
\end{tabular}

11. Langkah selanjutnya adalah menghitung formula dan akan digunakan untuk menghitung nilai akhir. Formula dihitung dengan cara harga terendah dari sebuah kriteria lukisan dibagi dengan jumlah perkalian dari setiap eigen vector kriteria pada tabel 5 dan subkriteria pada tabel 6 sampai 9 sesuai dengan variabel formula yang digunakan pada tabel 9 sehingga mendapatkan hasil seperti dibawah ini.

$$
\begin{aligned}
& \text { Formula A } 1=745000 /(0,4658 * 0,5204+ \\
& 0,0434 * 0,2926+0,057 * 0,1148+0,0907 \\
& * 0,0722)=\mathbf{2 7 7 7 4 4 3 , 7 8 5 8 7 5 2} \\
& \text { Formula A2 }=450000 /(0,2771 * 0,5204+ \\
& 0,0434 * 0,2926+0,057 * 0,1148+0,0907 \\
& * 0,0722)=\mathbf{2 6 4 6 4 5 7 , 8 3 5 8 2 3 4} \\
& \text { Fornula A3 }=255000 /(0,1611 * 0,5204+ \\
& 0,0434 * 0,2926+0,057 * 0,1148+0,0907 \\
& * 0,0722)=\mathbf{2 3 2 5 9 4 9 , 5 6 6 9 4 6 6} \\
& \text { Formula A4 = } 153000 /(0,096 * 0,5204+ \\
& 0,0434 * 0,2926+0,057 * 0,1148+0,0907 \\
& * 0,0722)=\mathbf{2 0 1 9 7 2 7 , 4 8 6 2 9 4 5}
\end{aligned}
$$

12. Dari hasil perhitungan formula maka dihasilkan nilai formula yang ada pada tabel berikut.

Tabel 10. Nilai Formula

\begin{tabular}{|l|c|}
\hline Formula & Nilai \\
\hline Formula A1 & 2777443,7858752 \\
\hline Formula A2 & 2646457,8358234 \\
\hline Formula A3 & 2325949,5669466 \\
\hline Formula A1 & 2019727,4862945 \\
\hline
\end{tabular}

13. Penentuan kriteria dari sebuah lukisan yang dipesan pelanggan.

Tabel 11. Kriteria Lukisan yang Dipesan

\begin{tabular}{|l|l|l|l|l|}
\hline Lukisan & UK & JO & KR & JL \\
\hline Lukisan 1 & A2 & 2 & R & RH \\
\hline Lukisan 2 & A4 & 1 & SR & RW \\
\hline
\end{tabular}

14. Langkah selanjutnya yang dilakukan adalah menghitung tarif jasa dengan cara menjumlahkan tiap perkalian eigen vector subkriteria pada tabel 11 dengan eigen vector kriteria. Dari penjumlahan perkalian tersebut kemudian dikalikan dengan nilai formula pada tabel 10 sesuai dengan ukuran kertas yang digunakan sehingga mendapatkan nilai atau tarif seperti dibawah ini.

$$
\begin{gathered}
\text { Lukisan } 1=2646457,8358234 *((0,2771 * \\
0,5204)+(0,0655 * 0,2926)+(0,2477 * \\
0,1148)+(0,0907 * 0,0722))=\mathbf{R P ~ 5 2 4 . 9 9 8} \\
\text { Lukisan } 2=2019727.4862945 *((0.096 * \\
0.5204)+(0.0434 * 0.2926)+(0.5733 * \\
0.1148)+(0.1862 * 0.0722))=\mathbf{R p ~ 2 8 6 . 6 4 5}
\end{gathered}
$$

15. Dari hasil perhitungan didapatkan tarif lukisan seperti berikut.

Tabel 12. Tarif Lukis

\begin{tabular}{|l|l|l|l|l|l|}
\hline Lukisan & UK & JO & KR & JL & Tarif \\
\hline Lukisan 1 & A2 & 2 & R & RH & Rp 524.998 \\
\hline Lukisan 2 & A4 & 1 & SR & RW & Rp 286.645 \\
\hline
\end{tabular}

\section{HASIL DAN PEMBAHASAN}

4.1 Implementasi

Implementasi sistem merupakan tahap dimana sistem diwujudkan kedalam sebuah aplikasi berbasis website berdasarkan rancangan yang dipaparkan pada bab sebelumnya.

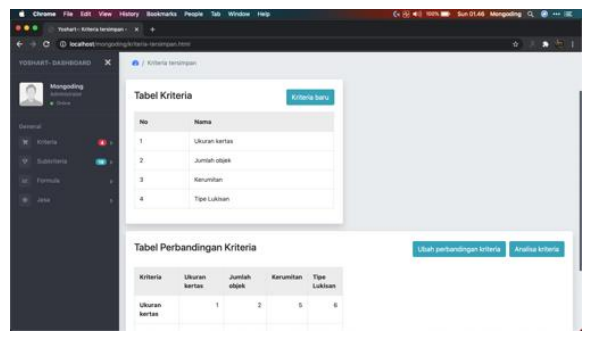

Gambar 4. Tampilan Halaman Kriteria Tersimpan
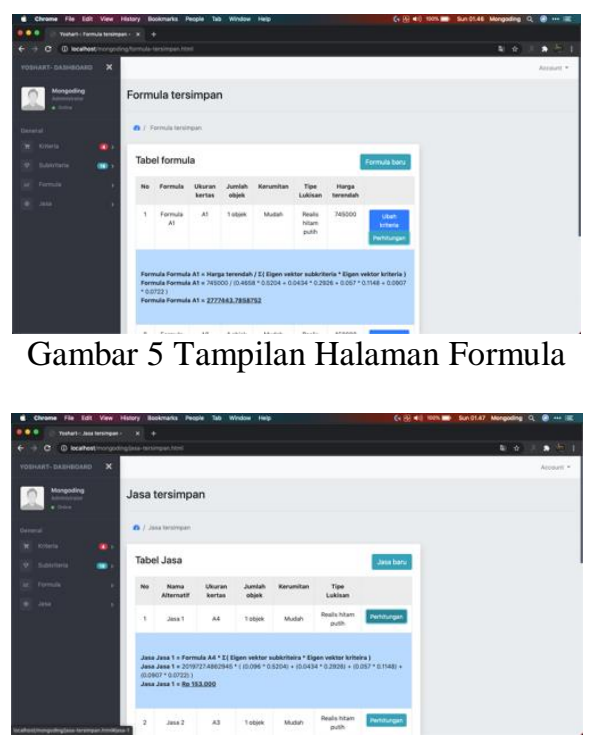

Gambar 6. Tampilan Halaman Jasa 
Gambar 6 merupakan halaman dimana seluruh penetapan tarif jasa lukis disimpan. Dari gambar 6 itu juga user atau pelukis dapat menghitung tarif lukisan yang akan diberikan kepada pelanggannya

\subsection{Pengujian White Box}

Dalam pengujian white box terdapat beberapa tahapan yang perlu dilakukan, diantaranya membuat flow graph notation, menghitung cyclomatic complexity, menentukan independent path, menyiapkan kasus uji setiap jalur bebas dan menghitung graph matrix.

Langkah awal dalam pengujian white box adalah merubah pseudocode penetapan jasa menjadi flow graph notation. Pada tahap ini pseudocode penetapan jasa diubah menjadi flow graph notation sehingga menjadi seperti gambar 7 .

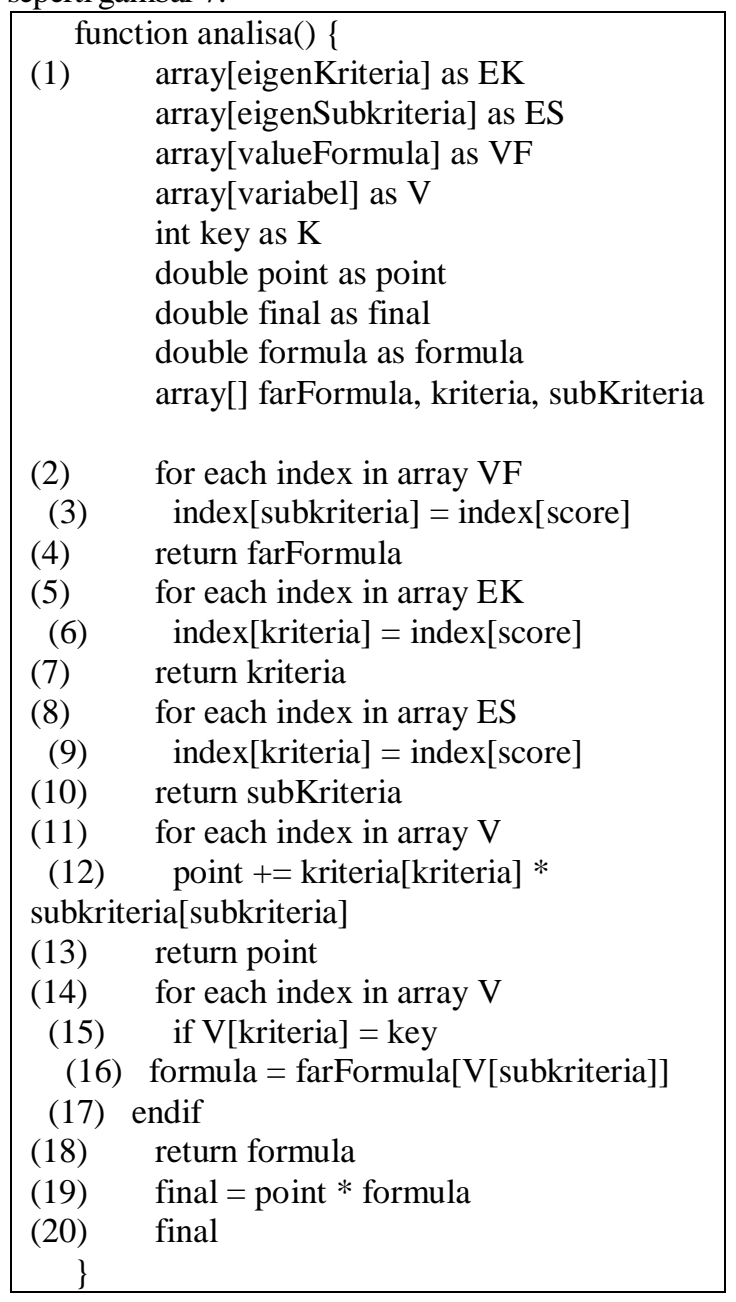

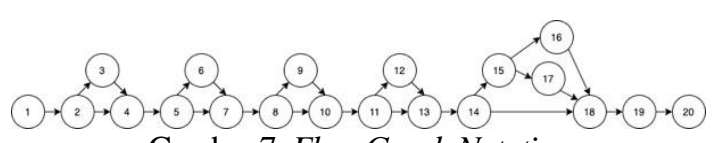

Gambar 7. Flow Graph Notation

Dari gambar 7 dapat diketahui:

$\begin{array}{ll}\text { Jumlah busur (E) } & =25 \\ \text { Jumlah simpul (N) } & =20 \\ \text { Jumlah region (R) } & =7 \\ \text { Jumlah predikat (P) } & =6\end{array}$

Langkah selanjutnya adalah dengan menghitung cyclomatic complexity. Untuk mendapatkan nilai cyclomatic complexity dari gambar 7 maka dilakukan perhitungan dengan rumus:

$$
\begin{aligned}
\mathrm{V}(\mathrm{G}) & =\mathrm{E}-\mathrm{N}+2 \\
& =25-20+2 \\
& =7 \\
\mathrm{~V}(\mathrm{G}) \quad & =\mathrm{P}+1 \\
& =6+1 \\
& =7
\end{aligned}
$$

Dari hasil perhitungan cyclomatic complexity menggunakan rumus 1, rumus 2 dan jumlah region yang terdapat pada gambar 9 mendapatkan nilai yang sama yaitu 7 , sehingga dapat disimpulkan rancangan sistem memiliki algoritma yang terstruktur, kode ditulis dengan baik, memiliki kemampuan pengetesan tinggi, kemudian rancangan sistem membutuhkan biaya dan usaha yang rendah.

\subsection{Pengujian Black Box}

Adapun kelas uji yang diujikan yaitu fungsi

\begin{tabular}{|c|c|c|}
\hline Data Uji & Butir Uji & $\begin{array}{c}\text { Jenis } \\
\text { Pengujian }\end{array}$ \\
\hline Fungsi login & $\begin{array}{l}\text { Verifikasi proses } \\
\text { login }\end{array}$ & Black box \\
\hline $\begin{array}{l}\text { Halaman } \\
\text { kriteria }\end{array}$ & $\begin{array}{l}\text { a. Tambah data } \\
\text { kriteria } \\
\text { b. Lihat data } \\
\text { kriteria } \\
\text { c. Perbandingan } \\
\text { kriteria }\end{array}$ & Black box \\
\hline $\begin{array}{l}\text { Halaman } \\
\text { subkriteria }\end{array}$ & $\begin{array}{l}\text { a. Lihat } \\
\text { subkriteria } \\
\text { b. Tambah } \\
\text { subkriteria } \\
\text { c. Perbandingan } \\
\text { subkriteria }\end{array}$ & Black box \\
\hline $\begin{array}{l}\text { Halaman } \\
\text { formula }\end{array}$ & $\begin{array}{l}\text { a. Lihat formula } \\
\text { b. Tambah } \\
\text { formula } \\
\text { c. Edit formula }\end{array}$ & Black box \\
\hline Halaman jasa & $\begin{array}{l}\text { a. Lihat tarif jasa } \\
\text { b. Tambah jasa }\end{array}$ & Black box \\
\hline
\end{tabular}
login, fungsi pada halaman kriteria, fungsi pada halaman subkriteria, fungsi pada halaman formula, dan fungsi pada halaman jasa.

Tabel 14. Kelas Uji Black box

Setelah dilakukan pengujian dengan 5 butir kelas uji dengan menggunakan metode Black box maka dihasilkan nilai sebagai berikut.

\footnotetext{
Persentase keberhasilan $=$

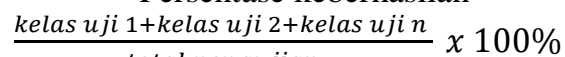
total pengujian

Persentase keberhasilan $=\frac{4+7+7+7+5}{30} \times 100 \%=$
} $100 \%$ 
Dari hasil uji presentasi tersebut maka fiturfitur sistem sudah sesuai dengan spesifikasi sitem yang dibutuhkan.

\subsection{Pengujian AHP}

Dalam pengujian AHP yang dilakukan adalah membandingkan rata - rata hasil penentuan harga dari perkiraan para pelukis komunitas lukis BlitArt, dan perhitungan AHP dengan mengunakan aplikasi yang telah dibuat. Alternatif yang diuji adalah alternatif lukisan berdasarkan dari wawancara dengan para pelaku usaha lukis. Hal ini bertujuan untuk mengetahui tingkat kesesuaian antara perhitungan AHP dengan perkiraan. Untuk perbandingannya dapat dilihat pada tabel 15.

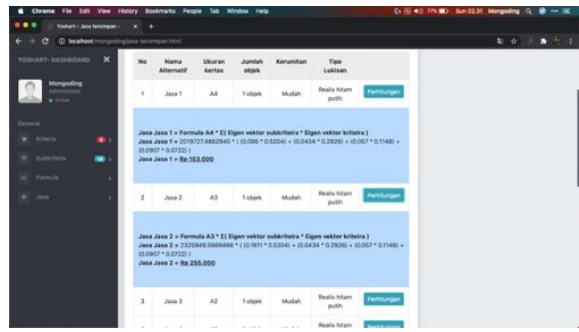

Gambar 8. Pengujian AHP dengan Aplikasi

Tabel 15. Tabel Perbandingan Tarif jasa

\begin{tabular}{|c|c|c|c|c|}
\hline \multirow{2}{*}{ No } & Lukisan & \multicolumn{2}{|c|}{ Lukisan } & $\begin{array}{c}\text { Keses } \\
\text { uaian }\end{array}$ \\
\cline { 3 - 5 } & & $\begin{array}{c}\text { Rata-rata tarif } \\
\text { perkiraan } \\
\text { pelukis }\end{array}$ & $\begin{array}{c}\text { Perhitung } \\
\text { an AHP }\end{array}$ & \\
\hline 1 & A4, 1, M, RH & 153.000 & 153.000 & Sesuai \\
\hline 2 & A3, 1, M, RH & 255.000 & 255.000 & Sesuai \\
\hline 3 & A2, 1, M, RH & 450.000 & 450.000 & Sesuai \\
\hline 4 & A1, 1, M, RH & 745.000 & 745.000 & Sesuai \\
\hline 5 & A4, 2, M, RH & 209.000 & 210.237 & Sesuai \\
\hline 6 & A3, 2, R, RH & 320.000 & 320.915 & Sesuai \\
\hline 7 & A2, 2, R, RH & 529.000 & 524.998 & Sesuai \\
\hline 8 & A4, 1, SR, RW & 265.000 & 286.645 & Sesuai \\
\hline 9 & A3, 1, SR, RW & 435.000 & 408.907 & $\begin{array}{c}\text { Tidak } \\
\text { sesuai }\end{array}$ \\
\hline 10 & A2, 1, SR, RW & 755.000 & 625.115 & $\begin{array}{c}\text { Tidak } \\
\text { sesuai }\end{array}$ \\
\hline 11 & A4, 1, S, KH & 177.000 & 192.104 & Sesuai \\
\hline 12 & A4, 2, S, KH & 212.000 & 205.136 & Sesuai \\
\hline 13 & A3, 1, S, KH & 320.000 & 300.033 & Sesuai \\
\hline 14 & A3, 2, S, KH & 390.000 & 315.040 & Sesuai \\
\hline 15 & A4, 1, S, KW & 260.000 & 214.407 & $\begin{array}{c}\text { Tidak } \\
\text { sesuai }\end{array}$ \\
\hline 16 & A3, 1, R, KW & 445.000 & 359.277 & $\begin{array}{c}\text { Tidak } \\
\text { sesuai }\end{array}$ \\
\hline & & & & \\
\hline
\end{tabular}

\section{Keterangan:}

Sesuai : Perkiraan pelukis sama dengan perhitungan AHP.

Tidak sesuai : Perkiraan pelukis tidak sama dengan perhitungan AHP. Toleransi selisih kesesuaian 25000

Berdasarkan tabel 1 terdapat perbedaan antara penentuan tarif dengan metode AHP dengan penentuan tarif dari pelukis. Dari 16 perhitungan yang ada, terdapat
8 tarif yang yang sama. Hal ini terjadi karena para pelukis hanya menetapkan berdasarkan angan-angannya saja. Tingkat kesalahan perhitungan penetapan tarif pelukis dengan metode AHP dapat dihitung dengan rumus:

$$
\begin{aligned}
& \text { Persentase Kesalahan }=\frac{\sum \text { data tidak sesuai }}{\sum \text { data pengurutan }} \times \\
& 100 \% \\
& \text { Persentase Kesalahan }=\frac{4}{16} \times 100 \% \\
& \text { Persentase Kesalahan }=25 \%
\end{aligned}
$$

Berdasarkan perhitungan diatas maka dapat disimpulkan bahwa selama ini pelukis menetapkan tarif jasanya 25000 lebih tinggi dari batas toleransi dengan presentase kesalahan 25\%. Namun disisi lain hal ini juga merupakan hal baik karena rata - rata dari tarif para pelukis berada diatas batas tarif terendah dari yang dihasilkan oleh perhitungan AHP.

\section{KESIMPULAN DAN SARAN \\ 5.1 Kesimpulan}

Berdasarkan penelitian yang telah dilakukan maka dapat disimpulkan sebagai berikut:

1. Perancangan aplikasi sistem pendukung keputusan penentuan tarif jasa lukis foto menggunakan metode AHP dilakukan dengan beberapa tahap yakni membuat flowchart sistem, menentukan kriteria dan subkriteria yang akan digunakan kemudian membuat aplikasi itu sendiri dilanjut dengan pengujian sistem dengan metode black box dan white box. Pengimplementasian aplikasi sistem pendukung keputusan penentuan tarif jasa lukis pengguna atau user harus memasukkan kriteria dan subkriteria terlebih dahulu yang akan digitung nilai eigen vektornya dengan menggunakan metode AHP. Kemudian sebelum menghitung tarif pengguna atau user juga harus membuat atau mengisi formula dari masing-masing kriteria lukisan baru setelah itu bisa menghitung tarif jasa lukis.

2. Pengujian aplikasi sistem pendukung keputusan penentuan tarif jasa menggunakan beberapa cara, yaitu menggunakan metode pengujian black kbox yang mendapatkan nilai total $100 \%$ hal ini menunjukkan penilaiannya tergolong 'Sangat Baik', yang kedua menggunakan metode white box dari hasil perhitungan cyclomatic complexity menggunakan rumus 1 , rumus 2 dan jumlah region yang terdapat pada gambar 7 mendapatkan nilai yang sama yaitu 7 , sehingga dapat disimpulkan rancangan sistem memiliki algoritma yang terstruktur, kode ditulis dengan baik, memiliki kemampuan pengetesan tinggi, kemudian rancangan sistem membutuhkan biaya dan usaha yang rendah. 


\subsection{Saran}

Adapun saran yang diberikan untuk penelitian kedepannya adalah sebagai berikut:

1. Pada penelitian ini masih terdapat banyak kekurangan, penulis berharap untuk penelitian selanjutnya bisa mengurangi presentase tingkat kesalahan dengan cara menambahkan lagi parameter-parameter agar perhitungan bisa lebih akurat.

2. Untuk penelitian selanjutnya sistem pendukung juga bisa diterapkan bukan hanya untuk penetapan harga lukis foto saja, tapi juga dapat untuk sektor usaha yang lain.

\section{DAFTAR PUSTAKA}

[1] Bekti, Humaira' Bintu. 2015. Mahir Membuat Website dengan Adobe Dreamweaver CS6, CSS dan JQuery. Yogyakarta: Andi.

[2] Simon K. 2020. DIGITAL 2020: INDONESIA, https://datareportal.com/reports/digital-2020indonesia. Diakses tgl 23 Mei 2020

[3] Abang M.Zaid Wahyu, N. S. 2013. Sistem Pendukung Keputusan Pemilihan Mata Kuliah Pilihan Menggunakan Metode Analytic Hierarchy Process (Studi kasus Jurusan Teknik Elektro Fakultas Teknik Universitas Tanjungpura).

[4] Daihani, D. U. 2001. Komputerisasi Pengambilan Keputusan : Panduan Langkah demi Langkah Mengembangkan Sistem Pendukung Keputusan Berbasis Komputer. Jakarta : PT. Elex Media Komputindo.

[5] Turban E, Aronson, Jay E \& Liang, Teng-Ping. 2005. Decission Support Systems and Intelligent Systems Edisi 7 Jilid 2. Yogyakarta: Andi.

[6] Saaty, T. L. 2008. Decision Making with Analytical Hierarchy Process. International Journal Services Sciencess, Vol 1, No 1 